\title{
INTERVIEW WITH ZOHAR SHAVIT
}

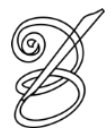 \\ Lia A. Miranda de LIMA* \\ University of Brasilia, Brazil
}

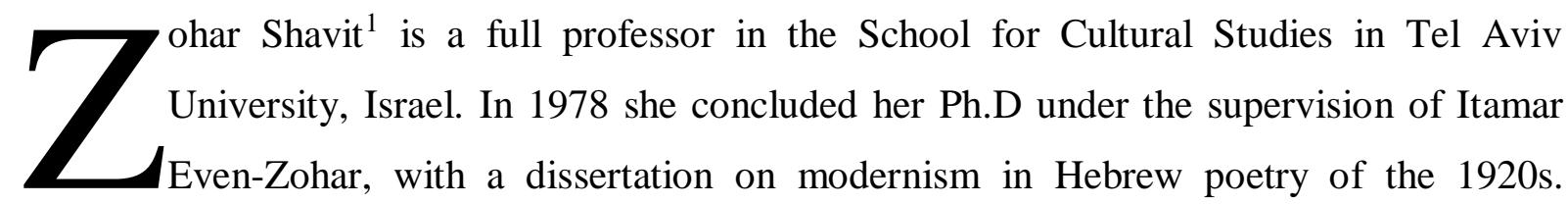

Departing from the fundaments of Polysystems theory, the author has been presenting, since the 1980s, innovative reflexions in the field of children's literature (CL), many of which regarding translation and international traffic of CL. Besides her best-known work, Poetics of Children's Literature (1986), Shavit has written an important group of academic articles and book chapters in which she deals with ambivalence in CL, with the need to formulate a poetics for its study, with the role of translations in the formation of Hebrew CL, with the phenomenon of cultural interference, with the canon.

In this interview, Shavit tells us how she has developed her interested in children's literature, having become one of the main references in the field. She also makes clear some key points in her work, such as the notions of system and ambivalence, and her historical model of the development of children's literature. Finally, she discusses the paths of contemporary research on CL and translation.

A Portuguese full version of this interview follows at the end of this article.

1) What led you to be interested in children's literature and translation? Can you tell us a little about your academic story?

I was always attracted to children's literature and translation and in fact, as a student I made my living by translating books, most of them for children. I believe that the first book I translated was Hugh Lofting's The Story of Dr. Dolittle (1975). However, at the seventies, writing a doctorate thesis on children's literature in the department of literature or in any other department in the faculty of humanities, was out of the question. So I wrote my PhD thesis on another fascinating theme, which dealt with the construction of Hebrew culture in Palestine Eretz-Israel. 
I was 27 years old when I submitted my thesis and I did not want to spend the rest of my life working on the same questions and themes of my doctorate dissertation (to which, however, I came back at a later stage of in my career). So I decided to start something new, and this something new was research of children's literature. I made this choice not only because I am so fond of children's literature, but also because of the huge research potential which is hidden in the field. At that time the study of children's literature was not yet considered legitimate in cultural studies; but children's literature itself craved to be studied - there was so much to be done and it was all so new and so interesting! I was consciously willing to break a new path, something that not too many scholars have done thus far. Indeed, much was written about children's literature, but often from a pedagogical point of view based on a very traditional theoretical framework, certainly not a cutting-edge theory, as was Itamar EvenZohar's Polysystems theory, which served as the conceptual framework for my work.

In this framework the "literary system" is conceived of as a theoretical concept that describes a network of dynamic relations between literary groups, literary institutions, texts, repertoires and audiences, a reticulation of relations changing from period to period in accordance with what is considered "literature" in a given society.

Nonetheless, in hindsight I must admit that the decision to deal with children's literature turned out to be far from being simple, because I had to "prove" my scholarly value, so to speak in other fields as well. Indeed, if you look at my list of publications, you can see that more than half of my books and articles do not deal with "children's literature."

Nowadays I think the academic world is much more tolerant, open, and ready to accept the study of any theme not because of its privileged cultural status, but because of its potential for research. In other words, we do not identify any more the "cultural" value attributed to a certain object with the scholarly interest we may find in it.

Now, why translation? The main reason for my great interest in translation lies in the fact that translation always involves a dialogue between at least two systems. When one deals with translations one always enters into discussion of cultural dialogue/s. Thus for instance, translation, or rather transfer (to use Even-Zohar's notion) from adult to children's children also involves a dialogue between two systems differentiated by the construct of their addresses. And the analysis of this dialogue opens the door to the exploration of many phenomena that otherwise are more difficult to explore. In addition, in Hebrew culture, in Hebrew-Jewish culture, like in many other small cultures, translation plays an extremely significant role in both the construction of the system and later on in its maintenance. 
Modern Jewish culture has had two beginnings: the first one in Europe, with the Haskalah movement (the Enlightenment movement), and the second with the building of a new Jewish national society in Palestine-Eretz-Israel. In both cases translations played a major role in giving them legitimization, as was the case during the Haskalah movement, and by filling the system, as was the case towards the end of the $18^{\text {th }}$ century and then again at the beginning of the $20^{\text {th }}$ century. In both, the Hebrew-Jewish system used to translate texts from cultures that enjoyed a high status, such as the German, the Russian, the English or the French. The massive translational activity responded to the need to build a new system from scratch. Translations which were available made this task much easier. This is the main reason for the significant place that translations occupy in my work. As a matter of fact, I do not deal only with translations, but you are right in suggesting that I focus on translations, and sometimes mainly on translations.

2) Gideon Toury and Itamar Even-Zohar are fundamental references on Translation Studies all over the world. How do you see the theoretical importance of their work for the research on children's literature more specifically?

Itamar Even-Zohar and the late Gideon Toury indeed became the pillars of Translation Studies and the work of Itamar Even-Zohar was a breakthrough in culture research. Both Gideon Toury and I were students of Itamar Even-Zohar, who was our great mentor and both of us have used his Polysystems theory as the basis for our work. Itamar Even-Zohar has constructed a theory, or a set of theoretical notions, where children's literature, or any other system in culture could fit in. When you use the notions of Polysystems theory, you can deal with children's literature without any sense of inferiority, in the same way you deal with literature for adults, literature for women, literature for any gender or any other social group. This theory is not pejorative; it enables a discussion which is free of any judgement. You analyze a certain phenomenon in culture not because of its so-called "aesthetic" value, but because it allows you to ask interesting questions, and of course, the most important advantage of this theory is that it offers the possibility to study the dynamics of culture in its multi-relations facet.

I find this theoretical conception fruitful because it places the discussion in the context of culture in its totality, especially in terms of its relations with other literatures as well as other societal systems. The whole idea is that you discuss dynamics of culture, and not static entities. 
The value of my work, I believe, lies in the exploration of the dynamics of children's literature, among which paramount prototypes and patterns which characterize children's literature, such as changing notions of childhood, ambivalence, poor self-image, turning a disadvantaged peripheral status into an advantage - all these derive from the understanding of children's literature as part of a larger dynamic polysystem.

Furthermore, as we all know, it is the existence of a reservoir of new questions, or the very existence of its potential, which ensures the ongoing vitality of any discipline. EvenZohar's theory enables us to propose new questions and to release children's literature from traditional and worn-out questions of either pedagogic, social studies, education or literary studies and discuss it instead in the framework of semiotics of culture. Working in the framework of semiotics of culture allows us to deal with the multi-systemic situation typical of children's literature. It allows us to inquire into children's literature in the broadest possible context - into its multi-relationship with social norms, literary norms and educational norms, and analyze how texts for children are a product of this complicated net of relationships. Furthermore, it allows us to examine how in turn texts for children shape societal ideals and ideas and take part in transforming them into new paradigms.

3) In an article from 1994 (Beyond the Restrictive Frameworks of the Past: Semiotics of Children's Literature - A New Perspective for the Study of the Field), you stated that children's literature was "the Cinderella of literary studies." 25 years later, do you believe that this remains the case?

Yes and no. I believe that in most cases children's literature is still the Cinderella of literary studies. This context reminds me of the following anecdote: A well-known writer for children attends a cocktail party, when someone approaches him and asks: "What do you do for a living?" He answers: "I write for children." So this person says: "Oh, maybe I'll try it one day." In response, the writer asks him: "What do you do for living?" and he answers, "I'm a brain surgeon." So the writer comments: "Oh, maybe I'll try it one day."

There is a feeling that anyone can write for children and everyone can do research on children's literature because it is so simple and within reach. I believe that there is still a kind of patronizing attitude towards children's literature and towards its study. As a scholar you can "improve" your "academic status" and get a kind of academic certificate if you manage to "prove" yourself in other fields of research. 
There are two manifestations for this state of affairs. First of all - the gender: most scholars of children's literature are women, and this unfortunately, we must admit, is always a kind of sign for an inferior status of the field. A social field dominated by women suffers from less prestige than a field governed by men. Usually professions that are almost "free" from women enjoy a somehow higher position. This is the truth of the matter: when women enter the club, it becomes less prestigious, to quote Groucho Marx: "I Don't Want to Belong to Any Club That Will Accept Me as a Member.”

That being said, we do see that children's literature began to gain status as a legitimate academic field, not only in schools of education or pedagogy. In this sense, I think it is an "improved Cinderella." The problem also derives from the tendency of scholars of children's literature to adopt this image and not to dare to bring new paradigms; they prefer to stick to worn-out notions or theories that previously were used by the study of adult literature. When they are applied to the study of children's literature, not only they are often not adequate, but because they adopt theoretical notions that are already outdated, they preserve the unprivileged status of the study of children's literature. It is a vicious circle that creates a sentiment of left behind of children's literature's scholars. But this is not always true. In some cases it is the study of children's literature that is at the frontage of cultural studies because of its ability to shed light on complicated cultural issues. Thus, on the one hand, the studies on children's literature often remain not very daring and rather conservative and at the same time, some of the research done is indeed a breakthrough and could not be have been accomplished in any other field of study, because of the unique perspectives it offers.

4) In your works, when studying the development of children's literature, we see a special emphasis on translations. Could you talk a little about the importance of Translation Studies for the research in children's literature?

Children's culture and children's literature in particular are always a result of translation or "transfer." Translations, as I have said before, always enable us to approach a certain object from various and different perspectives. As Gideon Toury taught us, translation is based on the tension between two poles: equivalency and adequacy. The analysis of this tension enables us to uncover patterns and structural features that are difficult to expose when you deal with one text only, because the comparison of two or more texts can lead to detecting new readings and interpretations of the same text/s. 
The analysis of the translator's work always involves a deautomatization of both the source and the target system when a multitude of questions are raised: "Why did you phrase it that way? Why did you turn a concrete description into an abstract one? Why are there those additions or omissions? etc., etc. Such an analysis sometimes becomes very telling and you can learn a lot on each of the cultures in question - the target and the source. Since I am interested in culture/s in the large sense, I find the analysis of translations very instrumental for the study of culture/s.

5) In the article The Historical Model of the Development of Children's Literature (1994), you develop an idea already presented in 1986 Poetics of Children's Literature, which is the universality of a general structure of development for all children's literatures. This idea has been criticized by Emer O'Sullivan (Comparative Children's Literature, 2000), who states that some literatures may not fit this "north-west European model." Could you comment a little on that?

On a conceptual abstract level, this model is certainly valid. It is less so when we come to more concrete levels. Thus, it depends on how broad the understanding of the notion of universality is. Nevertheless, I believe it is rewarding to deal with universality and to see how this conglomerate of two systems and more and the existence of an a-priory constant dual readership, always participates in the construction of what we label "children's literature."

Children's literature always operates under the constraints of at least two systems, whereas adult literature is more "liberated," and has much more freedom to operate. Even when texts for children try to challenge these constraints, for instance those of the educational system, they are still there, and must be taken into account. You always have in mind these two groups of readers - adults and children, which differ sustainably as a social construct. This is the case even when children's literature endeavors to challenge adult culture by pretending not to care about it, which by the way never really happens. In this sense, this model of duality is certainly valid and very helpful for our understanding of the child culture.

Undoubtedly, the opposition between the two systems - the educational and the literary as well as the opposition between adults and children - always determines the nature of children's culture.

6) Quite a few researchers, among which we can mention Göte Klingberg, have pointed out that translators of children's literature usually take more liberties when translating than 
translators of adult literature. Do you believe anything has changed in recent years regarding this general norm?

I think it has changed in the sense that in the $19^{\text {th }}$ century and the beginning of the $20^{\text {th }}$ translators used the source texts as raw material. They had the liberty to do anything they wanted in order to adjust text to the target system. Unfortunately for me I do not know Portuguese and thus I never studied the case of translations into Portuguese, but I am almost sure that this was true for translations into Portuguese, as it was with translations into Hebrew, Yiddish, French and German. This, however, is not the case any more. Translators are more and more expected to produce full and adequate translations.

As a case in point I can bring my last study of domestication in translations into Hebrew, which I recently presented in a conference in Granada, Spain. There I have discussed how this norm predominated translations into Hebrew. Everything was domesticated: first names, last names, foods, customs and holidays. Thus for example, a Christmas tree became a Hanukkah the nine-branched menorah that symbolizes the Jewish holiday, non-kosher foods were replaced by kosher foods (veal replacing pork), and Jewish prayers replaced the Christian. Sometimes it became ridiculous, because the illustrations presented in a picture books would show a swine while the text refers to a cow.

This norm is over. Translators are more and more expected nowadays to produce an adequate text and render the world presented in the source text without "converting" it. In this sense I think that major changes took place, at least in the literatures I study, although I cannot guarantee that it is true for other literatures.

7) In Poetics of Children's Literature and in other works you talk about ambivalent texts: texts with a diffuse status within the literary system, especially in what regards their implied readers - children and adults. How could we relate that notion to the more recent term crossover literature?

At a first glance there seem to be no real difference between the notions of ambivalent and crossover literature, because very often they refer to the same texts, they both deal with texts which at the same time address children and adults. But I contend that they are profoundly different because they represent totally different understanding of the cultural system - the difference between a dynamic and static understandings.

In the framework of traditional static conception, texts were classified into categories resembling drawers, which did not leave room for texts whose status is not unequivocal. Here 
exactly comes the concept of ambivalence which deals with texts located in more than "one drawer" and requires the possibility of analyzing the dualism of their status. Phrased differently, the concept "ambivalent text" refers to texts that enter simultaneously into more than one systemic opposition within mutually exclusive systems. In the case of ambivalent texts, the question of what system they belong to is of significance, since they play precisely with the point of their non- or dual membership. The theoretical possibility to investigate ambivalent status and contradictory functions is crucial, since our interest centers on a group of texts that belong officially to the system for children - although the fact that they are perceived and accepted as suitable for adults is a sine qua non for their success as texts for children. Thus, the whole idea of the notion of ambivalence (a Yuri Lotman's notion which I elaborated), is to point to the systemic dynamics. The notion of ambivalence pertains to exclusiveness, which means that we deal with a group of texts that cannot be accepted either by adult or by children's literature. They are excluded from both systems and accepted by both on the basis of their being excluded. Here we deal the reasons for their exclusion - the dynamics of exclusion, and how writers and publishers use this exclusion for inclusion. Crossover literature takes into account only inclusion, dealing with texts that are included both in children's and adult literatures. Here the end and the beginning are the same: you begin with texts that are included in both adult and children's literature and you end with them. But with the notion of ambivalence the end and the beginning are different. We begin with exclusion, which eventually becomes inclusion, but a very conditioned inclusion: you can be accepted by each of the systems only if you are accepted at the same time by both. The notion of ambivalence thus allows for a more delicate and much more sophisticated analysis. You take into account more factors, you try to understand what makes it work for both audiences. I have read several fine articles that deal with crossover literature and learned a lot. Still I think that the use of the notion of ambivalence would yield a more sophisticated analysis.

8) How do you believe recent studies in the field of children's literature have evolved in terms of leaving behind old methodologies, such as those provided by classical literary criticism?

As I said above, some scholars are highly conservative and tend to pose questions that were asked by scholars of adult literature 20 or 50 years ago. Others are even worse in my view because they seem to chase fashionable theories without asking themselves whether they are at all relevant to the field. Still many scholars are doing serious and valuable work. 
First of all, the study of the history of childhood and adolescence has achieved marvelous results. Very good scholarly works have come out, and are still coming. Moreover, scholars began to be very attentive to the developments in the field and to explore other media for children, such as children's games, illustration, films and theater and, of course, the whole issue of digital culture for children. Here scholars often find themselves in the foreground of culture studies. This is also true for studies of children's and youth leisure and the whole issue of Screen Agers.

Again, you find studies of child culture at two poles: some very advanced, and some very old-fashioned. The more advanced studies are done, to the best of my knowledge, mainly in Europe, in Scandinavian countries, in Germany, in England and France and the Spanishspeaking world; much less so is done in the United States. In the United States I find that most of the research is very conservative and at the same time there is a constant endeavor to be fashionable. Now they have discovered the gender studies, and you find a lot of works on gender and children's literature. Ten years ago it was the studies on racism or old age. I am not too fond of this kind of rapidly changing paradigms of research because they never get a chance to evolve seriously. Changing the scientific paradigms every five or ten years, does not leave enough room to mature properly.

You must also take into account that much of the research done is not accessible to me due to the language barrier, which is really very regrettable. I very much hope that more studies will get translated.

9) What do you believe are the most fruitful paths for contemporary research on children's literature, especially in what regards Translation Studies?

I have already pointed to the advantages of Polysystem theory and I would like to mention further the work of the late Pierre Bourdieu, particularly his notions of "fields" "cultural capital" and assets (les biens), which are of utmost importance for our work. These theoretical notions are very valuable for the study of translation, because they let you better analyze both the selection process of certain items for translation as well as their handling. For example, when you analyze the selection process, it is the cultural capital that usually determines whether you choose to translate a certain text, and how you choose to translate it. When a certain text enjoys high cultural value, if it is culturally highly ranked, translators would most likely will have fewer liberties in their treatment of the texts and endeavor to produce an adequate translation. 


\section{REFERENCES}

Klingberg, Göte. Children's Fiction in the Hands of the Translators. Lund: CWK Gleerup, 1986.

O'Sullivan, Emer. Comparative Children's Literature (Kinderliterarische Komparatistik). Translated by Anthea Bell. London and NY: Routledge, 2005.

Shavit, Zohar. Poetics of Children's Literature. Athens and London: The University of Georgia Press, 1986.

Shavit, Zohar. Beyond the Restrictive Frameworks of the Past: Semiotics of Children's Literature - A New Perspective for the Study of the Field. In: Ewers, H.-H.; Lehnert, G.; O’Sullivan, E. (org.). Kinderliteratur im interkulturellen Prozess: Studien zur Allgemeinen und Vergleichenden Kinderliteratur-wissenschaft. Stuttgart and Weimar: Verlag J.B. Metzlez, 1994. pp. 3-15.

Shavit, Zohar. The Historical Model of the Development of Children's Literature. In: Nikolajeva, M. (org.) Aspects and Issues in the History of Children's Literature. Westport, Connecticut and London: Greenwood Press, 1995. pp. 27-38. 


\title{
ENTREVISTA COM ZOHAR SHAVIT
}

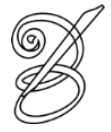 \\ Lia A. Miranda de LIMA \\ Universidade de Brasília, Brasil
}

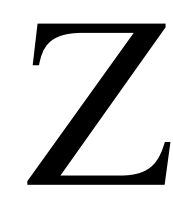

ohar Shavit é professora do departamento de Estudos Culturais da Universidade de Tel Aviv, Israel. Seu doutorado, defendido em 1978 sob a orientação de Itamar EvenZohar, teve como tema o modernismo na poesia hebraica da década de 1920. Partindo dos fundamentos da escola de Tel Aviv referentes à teoria dos Polissistemas, a autora tem apresentado, desde a década de 1980, reflexões pioneiras no campo da literatura infantil, muitas das quais concernentes à sua tradução e circulação internacional. Além de sua obra mais conhecida, Poetics of Children's Literature (1986), a autora legou um importante conjunto de artigos acadêmicos e capítulos de livros nos quais trata do caráter ambivalente da literatura infantil, da necessidade de se formular uma poética para seu estudo, da formação da literatura infantil hebraica a partir de traduções, do fenômeno da interferência cultural, do cânone.

Nesta entrevista, Shavit conta como passou a se interessar pela literatura infantil, tendo se tornado uma das principais referências na área. Ela também esclarece pontos-chave de sua obra, tais como as noções de sistema e ambivalência e seu modelo histórico de desenvolvimento da literatura infantil. Finalmente, Shavit discute os caminhos da pesquisa contemporânea em literatura infantil e tradução.

Esta é a versão em português da entrevista concedida a mim, por telefone, conforme texto em inglês reproduzido neste artigo.

1) O que a levou a interessar-se pela literatura infantil e pela tradução? Você pode nos falar um pouco sobre sua trajetória acadêmica?

Sempre tive atração pela literatura infantil e pela tradução e, na verdade, quando eu era estudante, ganhava a vida traduzindo livros, a maioria infantis. Acredito que o primeiro livro que traduzi tenha sido The Story of Dr. Dolittle (1975), de Hugh Lofting. Contudo, na década de 1970, escrever uma tese de doutorado sobre literatura infantil no departamento de literatura ou em qualquer outro departamento das ciências humanas estava fora de questão. Então escrevi 
minha tese sobre outro tema fascinante, que tratava da construção da cultura hebraica em EretzIsrael, Palestina.

Eu tinha 27 anos quando defendi minha tese e não queria passar o resto da vida trabalhando nas mesmas questões e temas do doutorado (aos quais, entretanto, eu voltei mais tarde em minha carreira). Então decidi começar algo novo, e essa novidade era a pesquisa em literatura infantil. Fiz essa escolha não apenas porque gosto tanto de literatura infantil, mas também por causa do imenso potencial de pesquisa oculto neste campo. Naquele tempo, o estudo da literatura infantil não era considerado legítimo nos estudos culturais; mas a literatura infantil em si mesma ansiava por ser estudada - havia tanto a ser feito, e tudo era tão novo e interessante! Eu estava conscientemente desejosa de abrir um novo caminho, algo que não muitos pesquisadores haviam feito até então. De fato, havia muita coisa escrita sobre literatura infantil, mas frequentemente sob um ponto de vista pedagógico, baseado em um arcabouço teórico muito tradicional - certamente não em uma teoria de ponta como era a teoria dos Polissistemas, de Itamar Even-Zohar, que serviu como arcabouço conceitual para o meu trabalho.

Nesse arcabouço, o "sistema literário" é concebido como um conceito teórico que descreve uma rede de relações dinâmicas entre grupos literários, instituições literárias, textos, repertórios e públicos, uma malha de relações que mudam de período a período de acordo com o que é considerado "literatura" em uma dada sociedade.

Todavia, olhando retrospectivamente, devo admitir que a decisão de lidar com a literatura infantil mostrou-se longe de ser simples, pois eu tive de "provar" meu valor acadêmico, por assim dizer, também em outros campos. De fato, se você olhar para minha lista de publicações, vai notar que mais da metade de meus livros e artigos não tratam de "literatura infantil".

Hoje em dia percebo o mundo acadêmico bem mais tolerante, aberto e pronto para aceitar o estudo de qualquer tema não por causa de seu estatuto cultural privilegiado, mas por causa de seu potencial de pesquisa. Em outras palavras, não identificamos mais o valor “cultural" atribuído a certo objeto com o interesse acadêmico que possamos encontrar nele.

Agora, por que tradução? A principal razão do meu grande interesse pela tradução repousa no fato de que ela sempre envolve um diálogo entre pelo menos dois sistemas. Quando se lida com tradução, sempre se entra na discussão de diálogo(s) cultural(is). Assim, por exemplo, a tradução ou, melhor dizendo, transferência (para usar a noção de Even-Zohar) do sistema adulto para o infantil também envolve um diálogo entre dois sistemas diferenciados 
pelo construto de seus destinatários. E a análise deste diálogo abre as portas para a exploração de muitos fenômenos que, de outra maneira, são muito difíceis de explorar. Além disso, na cultura hebraica, na cultura hebraico-judaica, como em muitas outras culturas pequenas, a tradução exerce um papel extremamente significativo tanto na construção do sistema quanto posteriormente, em sua manutenção.

A cultura judaica moderna tem dois inícios: o primeiro na Europa, como o movimento do Haskalá (o movimento Iluminista), e o segundo com a construção de uma nova sociedade nacional judaica na Palestina-Eretz-Israel. Em ambos os casos, as traduções exerceram um papel essencial, seja dando-lhes legitimidade, como foi o caso durante o movimento do Haskalá, seja preenchendo o sistema, como foi o caso por volta do fim do século XVIII e novamente no início do século XX. Em ambos, o sistema hebraico-judaico traduzia textos de culturas que desfrutavam de um estatuto elevado, como a alemã, a russa, a inglesa ou a francesa. A atividade tradutória massiva respondia à necessidade de construir um sistema novo desde o começo. As traduções que estavam disponíveis tornaram esta tarefa muito mais fácil. Esta é a principal razão para o lugar significativo que as traduções ocupam em meu trabalho. $\mathrm{Na}$ verdade, eu não trabalho apenas com traduções, mas você tem razão em sugerir que eu me concentro nas traduções, e algumas vezes principalmente nas traduções.

\section{2) Gideon Toury e Itamar Even-Zohar são referências essenciais nos Estudos da Tradução por} todo o mundo. Como você enxerga a importância teórica de sua obra para a pesquisa em literatura infantil mais especificamente?

Itamar Even-Zohar e o Gideon Toury tardio de fato se tornaram os pilares dos Estudos da Tradução, e o trabalho de Itamar Even-Zohar foi uma inovação na pesquisa cultural. Tanto Gideon Toury quanto eu fomos alunos de Itamar Even-Zohar, que foi nosso grande mentor, e ambos usamos sua teoria dos Polissistemas como a base do nosso trabalho. Itamar Even-Zohar edificou uma teoria, ou um conjunto de noções teóricas, na qual a literatura infantil, ou qualquer outro sistema dentro da cultura poderia se encaixar. Quando você usa as noções da teoria dos Polissistemas, você pode lidar com a literatura infantil sem qualquer senso de inferioridade, da mesma maneira como você lida com a literatura para adultos, para mulheres, para qualquer gênero ou grupo social. Essa teoria não é pejorativa; ela permite uma discussão livre de qualquer julgamento. Você analisa determinado fenômeno na cultura não por causa de seu chamado valor "estético", mas porque ele permite que você formule questões interessantes. E, claro, a 
vantagem mais importante dessa teoria é que ela oferece a possibilidade de estudar a dinâmica da cultura em sua faceta multirrelacional.

Acho frutífera esta concepção teórica porque ela situa a discussão no contexto da cultura em sua totalidade, especialmente em termos de suas relações com outras literaturas, bem como com outros sistemas societais. A ideia geral é que você discute a dinâmica da cultura, e não entidades estáticas.

O valor do meu trabalho, acredito, repousa na exploração da dinâmica da literatura infantil, no qual protótipos e padrões cruciais que caracterizam a literatura infantil - tais como mudanças nas noções de infância, a ambivalência, a fraca autoimagem, transformando em vantagem a desvantagem de seu estatuto periférico -, todos derivam da compreensão da literatura infantil como parte de um polissistema dinâmico mais amplo.

Além disso, como todos sabemos, é a existência de um reservatório de novas perguntas, ou a própria existência de seu potencial, que garante a vitalidade contínua de qualquer disciplina. A teoria de Even-Zohar nos permite propor novas perguntas e libertar a literatura infantil de questões tradicionais e desgastadas, seja dos estudos pedagógicos, sociais, educacionais ou literários, e discuti-la, em vez disso, no quadro da semiótica da cultura. Trabalhar dentro da semiótica da cultura nos permite lidar com a situação multissistêmica típica da literatura infantil. Permite que esquadrinhemos a literatura infantil no contexto mais amplo possível - em suas multirrelações com normas sociais, literárias e educacionais, e analisar como os textos para crianças são um produto dessa rede complicada de relações. Além disso, permite que examinemos como os textos para criança, por sua vez, moldam ideais e ideias sociais e participam da sua transformação em novos paradigmas.

3) Em artigo de 1994 (Beyond the Restrictive Frameworks of the Past: Semiotics of Children's Literature - A New Perspective for the Study of the Field), você declarou que a literatura infantil era a "Cinderela dos estudos literários". 25 anos depois, você acredita que esta situação permanece?

Sim e não. Acredito que, na maior parte dos casos, a literatura infantil ainda é a Cinderela dos estudos literários. Isso me lembra da seguinte história: um conhecido escritor para crianças está em um coquetel, quando alguém se aproxima e pergunta: "Em que você trabalha?" Ele responde: "Eu escrevo para crianças.” Então a pessoa diz: “Ah, talvez um dia eu experimente.” Em resposta, o escritor pergunta: “Em que você trabalha?", e ele responde: "Sou um neurocirurgião.” Então o escritor comenta: “Ah, talvez um dia eu experimente.” 
Há uma sensação de que qualquer um pode escrever para crianças e de que todos podem fazer pesquisa em literatura infantil, já que ela é tão simples e tão dentro do alcance. Acredito que ainda existe uma atitude condescendente em relação à literatura infantil e ao seu estudo. Como pesquisador, você pode "melhorar" seu "status acadêmico" e conquistar uma espécie de certificação acadêmica se conseguir se "confirmar" em outros campos de pesquisa.

Há duas manifestações desse estado de coisas. Antes de tudo - o gênero: a maior parte dos pesquisadores de literatura infantil são mulheres, e isso, infelizmente, precisamos admitir, é sempre uma espécie de sinal do estatuto inferior de um campo. Um campo social dominado por mulheres goza de menos prestígio que um campo governado por homens. Geralmente, profissões nas quais quase não há mulheres gozam de uma posição de certa forma mais elevada. Esta é a verdade: quando mulheres entram no clube, ele se torna menos prestigioso, para citar Groucho Marx: "Não quero fazer parte de nenhum clube que me aceite como membro".

Dito isto, vemos que de fato a literatura infantil começou a ganhar status como um campo acadêmico legítimo, não apenas nos cursos de educação ou pedagogia. Nesse sentido, acho que ela é uma "Cinderela melhorada". O problema advém também da tendência de os estudiosos de literatura infantil abraçarem essa imagem e não ousarem trazer novos paradigmas; eles preferem agarrar-se a noções desgastadas ou teorias que antes eram usadas para o estudo da literatura adulta. Quando são aplicadas ao estudo da literatura infantil, não apenas porque frequentemente são inadequadas, mas porque adotam noções teóricas já desatualizadas, elas preservam o estatuto desprivilegiado do estudo da literatura infantil. É um círculo vicioso que cria entre os pesquisadores de literatura infantil um sentimento de estarem sendo deixados para trás. Mas isso nem sempre é verdade. Em alguns casos, é o estudo da literatura infantil que está na dianteira dos estudos culturais devido à sua capacidade de lançar luz sobre questões culturais complicadas. Assim, por um lado, os estudos sobre literatura infantil permanecem não muito ousados e um tanto conservadores e, ao mesmo tempo, parte da pesquisa feita é de fato inovadora e não poderia ter sido levada a cabo em nenhum outro campo de estudo, por causa da perspectiva única que oferece.

4) Nos seus trabalhos, ao estudar o desenvolvimento da literatura infantil, vemos uma ênfase especial nas traduções. Você poderia falar um pouco sobre a importância dos Estudos da Tradução para as pesquisas em literatura infantil?

A cultura infantil e a literatura infantil em particular são sempre resultados de uma tradução ou "transferência". As traduções, conforme afirmei anteriormente, sempre nos 
permitem abordar certo objeto a partir de perspectivas várias e diversas. Como nos ensinou Gideon Toury, a tradução baseia-se na tensão entre dois polos: equivalência ou adequação. A análise desta tensão nos permite desvelar padrões e características estruturais que são difíceis de expor quando você lida apenas com um texto, pois a comparação de dois ou mais textos pode levar à detecção de novas leituras e interpretações do(s) mesmo(s) texto(s).

A análise do trabalho do tradutor sempre envolve uma desautomatização tanto do sistema fonte quanto do sistema alvo, quando uma multidão de questões são levantadas: "Por que você formulou a frase desta maneira? Por que você transformou uma descrição concreta em abstrata? Por que essas adições e omissões? etc., etc. Tal análise às vezes se torna muito reveladora e você pode aprender muito sobre cada uma das culturas em questão - a alvo e a fonte. Como estou interessada na(s) cultura(s) em sentido geral, acho a análise das traduções muito instrumental para seu estudo.

5) No artigo The Historical Model of the Development of Children's Literature (1995), você desenvolve uma ideia já presente em Poetics of Children's Literature, de 1986, que é a universalidade de uma estrutura geral de desenvolvimento para todas as literaturas infantis. Esta ideia foi criticada por Emer O'Sullivan (Comparative Children's Literature, 2000), que declara que algumas literaturas podem não se encaixar neste "modelo europeu norteocidental”. Você poderia tecer alguns comentários a este respeito?

Em um nível conceitual abstrato, esse modelo certamente é válido. Ele o é menos quando chegamos a níveis mais concretos. Assim, depende do quão ampla é a noção de universalidade. Contudo, creio que é recompensador lidar com a universalidade e ver como esse conglomerado de dois sistemas ou mais e a existência de um constante leitorado a priori duplo sempre participa na construção do que rotulamos como "literatura infantil".

A literatura infantil sempre opera sob as restrições de pelo menos dois sistemas, enquanto a literatura adulta é mais "livre", tem muito mais liberdade para operar. Mesmo quando textos para crianças tentam desafiar essas restrições, por exemplo, aquelas do sistema educacional, elas ainda estão lá, e devem ser levadas em consideração. Você sempre tem em mente esses dois grupos de leitores - adultos e crianças, que diferem substancialmente como construto social. Este é o caso mesmo quando a literatura infantil se esforça para desafiar a cultura adulta, fingindo não se importar com ela, o que, aliás, nunca acontece de fato. Nesse sentido, o modelo de dualidade é certamente válido e muito útil para nossa compreensão da 
cultura infantil. Sem dúvida, a oposição entre os dois sistemas - o educacional e o literário, bem como a oposição entre adultos e crianças - sempre determina a natureza da cultura infantil.

6) Alguns pesquisadores, entre os quais podemos mencionar Göte Klingberg (1986), apontaram que os tradutores de literatura infantil frequentemente atuam com mais liberdade que os tradutores de literatura adulta. Você acredita que alguma coisa mudou nos anos recentes em relação a esta norma geral?

Acho que algo mudou no sentido que, no século XIX e no início do XX, os tradutores usavam os textos fontes como material bruto. Eles tinham a liberdade de fazer o que bem entendessem a fim de ajustar o texto para o sistema alvo. Infelizmente, para mim, não sei português e, portanto, nunca estudei o caso das traduções para este idioma, mas tenho quase certeza de que isso foi verdade para as traduções para o português, assim como foi com traduções para o hebraico, o iídiche, o francês e o alemão. Agora, porém, este não é mais o caso. Espera-se cada vez mais que os tradutores produzam traduções integrais e adequadas.

Como exemplo posso trazer meu último estudo sobre a domesticação nas traduções para o hebraico, que apresentei recentemente em uma conferência em Granada, na Espanha. Lá eu discuti como essa norma predominava nas traduções para o hebraico. Tudo era domesticado: nomes, sobrenomes, alimentos, costumes e feriados. Então, por exemplo, uma árvore de natal se tornava um Hanuká - a menorá de nove braços que simboliza o feriado judaico -, os alimentos que não eram kosher eram substituídos por alimentos kosher (vitelo em vez de porco), e as orações judaicas substituíam as cristãs. Às vezes isso se tornava ridículo, porque as imagens dos livros ilustrados mostravam um suíno, enquanto o texto se referia a uma vaca.

Esta norma acabou. Hoje se espera mais e mais que os tradutores produzam um texto adequado e transmitam o mundo apresentado no texto fonte sem "convertê-lo". Nesse sentido, acho que uma mudança enorme aconteceu, pelo menos nas literaturas que eu estudo, embora não possa garantir que isso se aplique a outras literaturas.

7) Em Poetics of Children's Literature e em outros trabalhos você fala em textos ambivalentes: textos com um estatuto difuso dentro do sistema literário, em especial no que diz respeito a seus leitores implícitos - crianças e adultos. Como podemos relacionar esta noção ao termo mais recente "literatura crossover"?

Num primeiro olhar parece não haver nenhuma diferença real entre as noções de literatura ambivalente ou crossover, porque com muita frequência elas se referem aos mesmos 
textos, e ambas lidam com textos que se dirigem ao mesmo tempo a crianças e adultos. Mas eu defendo que elas são profundamente diferentes porque representam uma compreensão totalmente diversa do sistema cultural - a diferença entre compreensões estáticas e dinâmicas.

No quadro da concepção estática tradicional, os textos eram classificados em categorias semelhantes a gavetas, que não deixavam espaço para textos cujo estatuto não era inequívoco. É exatamente aqui que entra o conceito de ambivalência, que lida com textos situados em mais de "uma gaveta" e demanda a possibilidade de analisar a dualidade de seu estatuto. Formulado de outra forma, o conceito "texto ambivalente" se refere a textos que entram simultaneamente em mais de uma oposição sistêmica no interior de sistemas mutuamente excludentes. No caso de textos ambivalentes, a questão sobre a qual sistema pertencem é significativa, uma vez que eles jogam precisamente com seu não pertencimento, ou com seu duplo pertencimento. A possibilidade teórica de investigar estatutos ambivalentes e funções contraditórias é crucial, uma vez que nosso interesse está centrado em um grupo de textos que pertencem oficialmente ao sistema infantil - embora o fato de que sejam percebidos e aceitos como adequados para adultos é uma condição sine qua non para seu sucesso como textos para crianças. Assim, toda 274 a ideia da noção de ambivalência (uma noção de Yuri Lotman que eu elaborei) é apontar para a dinâmica sistêmica. A noção de ambivalência diz respeito à exclusividade, o que significa que lidamos com um grupo de textos que não podem ser aceitos nem pela literatura adulta, nem pela infantil. Eles são excluídos de ambos os sistemas, e aceito nos dois, com base no fato de serem excluídos. Aqui lidamos com as razões para sua exclusão - a dinâmica da exclusão, e como os escritores e editores usam essa exclusão para a inclusão. A literatura crossover leva em conta apenas a inclusão, lidando com textos que são incluídos tanto na literatura infantil quanto na adulta. Aqui, o fim e o princípio são o mesmo: você começa com textos que estão incluídos tanto na literatura adulta quanto na infantil e termina com eles. Mas com a noção de ambivalência, o fim e o princípio são diferentes. Começamos com a exclusão, o que afinal se torna inclusão, mas uma inclusão muito condicionada: você pode ser aceito por cada um dos sistemas somente se for aceito ao mesmo tempo por ambos. A noção de ambivalência, portanto, permite uma análise mais delicada e muito mais sofisticada. Você leva em conta mais fatores, você tenta entender o que faz o texto funcionar para os dois públicos. Já li vários bons artigos que lidam com a literatura crossover, e aprendi muito. Mas ainda penso que o uso da noção de ambivalência geraria uma análise mais sofisticada. 
8) Como você acredita que os estudos recentes no campo da literatura infantil evoluíram no sentido de abandonarem metodologias antigas, tais como aquelas oferecidas pela crítica literária clássica?

Como eu disse antes, alguns pesquisadores são altamente conservadores e tendem a fazer perguntas que foram feitas por pesquisadores da literatura adulta há 20 ou 50 anos. Outros são ainda piores a meu ver, porque parecem ir à caça de teorias da moda sem se perguntarem se elas são relevantes para o campo. Contudo, muitos pesquisadores têm feito um trabalho sério e valioso.

Em primeiro lugar, o estudo da história da infância e da adolescência alcançou resultados maravilhosos. Trabalhos acadêmicos muito bons surgiram e ainda estão surgindo. Além disso, os pesquisadores começaram a atentar para os desenvolvimentos nesse campo e a explorar outras mídias para as crianças, como jogos, ilustração, filmes e teatro e, é claro, toda a questão da cultura infantil digital. Aqui, os pesquisadores com frequência se encontram na dianteira dos estudos culturais. Isso também é verdade em relação aos estudos sobre o lazer infantil e juvenil e a toda a questão dos screenagers.

Mais uma vez, você encontra estudos da cultura infantil em dois polos: alguns muito avançados e alguns muito ultrapassados. Os estudos mais avançados estão sendo feitos, até onde sei, principalmente na Europa, nos países escandinavos, na Alemanha, na Inglaterra e na França e no mundo de língua espanhola. Muito menos é feito nos Estados Unidos. Nos Estados Unidos, percebo que a maior parte da pesquisa é muito conservadora e, ao mesmo tempo, há um constante esforço para seguir tendências. Agora descobriram os estudos de gênero, e você encontra vários trabalhos sobre gênero e literatura infantil. Há dez anos, eram os estudos sobre racismo ou velhice. Não sou muito entusiasta desse tipo de paradigma de pesquisa que muda tão rápido, porque eles nunca têm a chance de evoluir seriamente. Mudar os paradigmas científicos a cada cinco ou dez anos não deixa espaço suficiente para um amadurecimento adequado.

Você também deve levar em consideração que muito da pesquisa que é feita não está acessível para mim devido à barreira linguística, o que é de fato lamentável. Espero muito que mais estudos sejam traduzidos.

9) Que caminhos você acredita serem os mais promissores para a pesquisa contemporânea em literatura infantil, em especial no que diz respeito aos Estudos da Tradução?

Já apontei as vantagens da teoria dos Polissistemas e gostaria de mencionar, além disso, o trabalho mais tardio de Pierre Bourdieu, particularmente suas noções de "campos", "capital 
cultural" e "bens" (les biens), que são de suma importância para nosso trabalho. Essas noções teóricas são muito valiosas para o estudo da tradução, porque permitem que você analise melhor tanto o processo seletivo de certos itens para a tradução, como seu manejo. Por exemplo, quando você analisa o processo de seleção, é o capital cultural que normalmente determina se você vai escolher traduzir certo texto, e como decidirá traduzi-lo. Quando certo texto goza de um valor cultural elevado, e ele é ranqueado culturalmente no topo, os tradutores tenderão a tomar menos liberdades no tratamento do texto e a se esforçar por produzirem uma tradução adequada.

\section{REFERÊNCIAS BIBLIOGRÁFICAS}

KLINGBERG, Göte. Children's Fiction in the Hands of the Translators. Lund: CWK Gleerup, 1986.

O'SULLIVAN, Emer. Comparative Children's Literature (Kinderliterarische Komparatistik). Tradução Anthea Bell. Londres e NY: Routledge, 2005.

SHAVIT, Zohar. Poetics of Children's Literature. Atenas e Londres: The University of Georgia Press, 1986.

SHAVIT, Zohar. Beyond the Restrictive Frameworks of the Past: Semiotics of Children's Literature - A New Perspective for the Study of the Field. In: EWERS, H.-H.; LEHNERT, G.; O'SULLIVAN, E. (org.). Kinderliteratur im interkulturellen Prozess: Studien zur Allgemeinen und Vergleichenden Kinderliteratur-wissenschaft. Stuttgart e Weimar: Verlag J.B. Metzlez, 1994. p. 3-15.

SHAVIT, Zohar. The Historical Model of the Development of Children's Literature. In: NIKOLAJEVA, M. (org.) Aspects and Issues in the History of Children's Literature. Westport, Connecticut e Londres: Greenwood Press, 1995. p. 27-38.

\footnotetext{
* Lia A. M. de LIMA - Doutoranda em Literatura pela Universidade de Brasília (PósLIT/UnB), bolsista CapesDS. Mestre em Estudos da Tradução (2015) pela Universidade de Brasília. Bacharel em Letras-Tradução/Francês (2008) pela mesma instituição e em Comunicação Social - Jornalismo (2004) pela Universidade Federal de Minas Gerais (UFMG). Brasília, Distrito Federal, Brasil.

O presente trabalho foi realizado com apoio da Coordenação de Aperfeiçoamento de Pessoal de Nível Superior Brasil (CAPES) - Código de Financiamento 001.

Currículo Acadêmico: http://lattes.cnpq.br/8248385539458046.

ORCID: https://orcid.org/0000-0002-4932-8424

E-mail: liaamiranda@gmail.com

${ }^{1}$ Zohar SHAVIT - Tel Aviv, Israel.

Academic page: https://english.tau.ac.il/profile/zshavit Email: zshavit@tauex.tau.ac.il
} 